\title{
EFFECTIVE USE OFFRESHLY HARVESTED, FREEZ DRIED AND PROCESSED USE OF POMEGRANATE (Punica granatum L.) FRUITS IN PAKISTAN
}

\author{
Tahseen Fatima Miano ${ }^{12^{*}}$ \\ ${ }^{1 *}$ Erciyes University, Faculty of Food Engineering, Department of Food Engineering, Kayseri 38039, Turkey; \\ ${ }^{2 *}$ Sindh Agriculture University, Institute of Food Sciences and Technology, Tandojam 70060, Pakistan; \\ "Corresponding Author Tahseen Fatima Miano, e-mail: tahseenfm@yahoo.com;
}

Received December 2020; Accepted January 2021; Published February 2021;

DOI: https://doi.org/10.31407/ijees11.120

\begin{abstract}
This study is based on the effective use of freshly harvested, freeze, dried and processed use of pomegranate (Punica granatum L.) fruits in Pakistan, locally pomegranate is known as Anar. pomegranate is a seasonal fruit crop therefore, rich in many macro and micro food nutritional components to food diet of consumer by eating this in any form it active the immune system in terms of antioxidant, nutritional therapeutic, wound healing, thirst quenching and appetite properties. Pomegranate arils were always hold by outré hard cover and inside the arils were separated by white albedo membrane which gives a protection to the seed of anar. However, studies have shown that pomegranate juice and arils are rich in total carbohydrates and sugars, proteins and amino acids and also have an abundant source of vitamin C $226.8 \mathrm{mg}$, vit. K $44.2 \mathrm{mg}$ and folate $1.5 \mathrm{mcg}$. In conclusion this study focuses the health benefits of pomegranate as functional food ingredients in consumer diet to protect their health by consuming pomegranate as food supplement for health concerned.
\end{abstract}

Keywords: Pomegranate, antioxidant, vitamins, total carbohydrates. 